\title{
Teoria Geral da Administração: aplicação e resultados nas em- presas brasileiras
}

\section{Adriana Amadeu Garcia *}

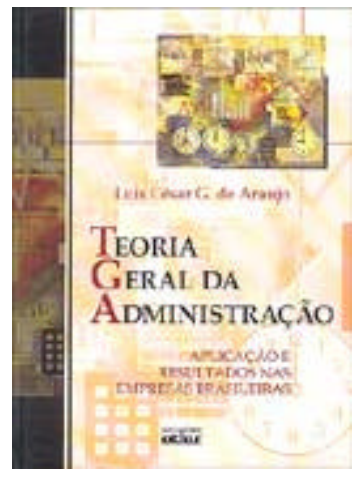

\author{
ARAUJ 0, Luis César G. de. Teoria Geral da Administração: aplicação e resulta- \\ dos nas empresas brasileiras. São Paulo: Atlas, 2004.
}

Teoria geral da administração: aplicação e resultados nas empresas brasileiras é destinado a um público não só de estudantes, mas também a "pessoas" em cargos de consultoria, cargos executivos e/ou empreendedoras. Aliás, empregar a palavra "pessoas" no lugar de consultor, executivo e/ou empreendedor não é um mero acaso. "Pessoa" é palavra que não define sexo. A idéia é enfatizar o fato das mulheres estarem conquistando um espaço substancial na área de gestão, até então dominada pelos homens. Assim, ao longo do texto o leitor perceberá claramente essa preocupação de fazer com que o público feminino se sinta incluído no mundo dos negócios.

Por conta disso, Luis César G. de Araujo dedica o primeiro capítulo ao seu público-alvo descrevendo alternativas de ação profissional, com o intuito de explicar as abordagens da teoria geral da administração. Nesse sentido, o autor não só fala das abordagens clássicas, comportamental, estruturalista, sistêmica e contingencial, como também estabelece uma relação entre elas e a realidade dos dias de hoje. Isso é feito, recorrendo-se a exemplos bastante claros, indicando para o leitor que na evolução do pensamento administrativo, as abordagens não podem ser vistas isoladamente, pois muitas vezes "convivem" simultaneamente.

Além de incluir o público feminino no contexto organizacional e relacionar o pensamento de Taylor e de seus seguidores com a realidade atual, a obra de Luis César tem um diferencial em relação a outros livros que se propõem a estudar as teorias administrativas já consagradas. Seu estudo trata a questão da interdisciplinaridade da área administrativa, mostrando as demais áreas de uma organização -como, por exemplo, gestão de pessoal e marketing -falando de sua importância para a empresa e apontando para a necessidade dos gestores entendêlas.

Seguindo a evolução do pensamento administrativo, Araujo apresenta as abordagens que ele chama de contemporâneas, que são as tecnologias de gestão organizacional, amplamente empregadas nos dias de hoje. O balanced scorecard (BSC) e a terceirização são exemplos dessas tecnologias

Teoria geral da administração: aplicação e resultados nas empresas brasileiras também apresenta os resultados e análises de duas pesquisas feitas no Brasil, e o faz para confirmar a necessidade de se conhecer as já referidas tecnologias de gestão e sua importância no mundo empresarial. Aliás, cabe observar que pela necessidade de que resultados apurados em empresas situadas no Brasil fossem trabalhados por estudiosos, mais uma pesquisa teve seus resultados e análises expostos nesta obra. A diferença é que se nas duas pesquisas citadas ante-

Mestranda em Administração Pública pela EBAPE/FGV. E-mail: aagarcia@ fgv.br. 
riormente foram abordadas a utilização das tecnologias de gestão, nesta, intitulada Empresas brasileiras e demandas de estruturação e de ação organizacional, foram trabalhadas quatro variáveis: organização, ambiente, gestão de pessoas e responsabilidade social. O objetivo foi identificar a forma pela qual empresas brasileiras ou estrangeiras que atuam no Brasil, mais especificamente nos estados do Rio de Janeiro e de São Paulo, atendem às demandas de estruturação para conseguir vantagens competitivas significativas.

O caráter inovador da obra de Luis César G. de Araujo não se limita aos aspectos já comentados. Fugindo de qualquer norma acadêmica, com base numa experiência "bastante real" -que faz o leitor, por vezes, se identificar com certas situações -, o livro fala das primeiras dificuldades enfrentadas pelos que decidem entrar no mundo dos negócios. O autor não apenas expõe essas dificuldades, mas também disponibiliza ao leitor algumas ferramentas que possibilitam ao iniciante superar tais obstáculos.

Outra novidade diz respeito ao profissional que quer abrir seu próprio negócio, tema pouco explorado na academia, pelo fato da cultura brasileira reforçar a idéia de que para ser empresário é preciso estar respaldado por uma grande organização. Ao trabalhar uma perspectiva diferente da que é predominante, o estudo de Luis César G. de Araujo funciona como um estímulo ao espírito empreendedor do brasileiro.

Teoria geral da administração: aplicação e resultados nas empresas brasileiras termina com um capítulo que fala de como conquistar a excelência nas organizações. Para isso aborda temas como estratégias, responsabilidade social, ética empresarial e transparência; assuntos de extrema relevância para quem quer atuar no ambiente organizacional. O caráter inovador, a linguagem informal, bastante próxima do seu público-alvo, e a praticidade da obra refletem uma tendência do mundo dos negócios, onde o tempo muitas vezes é o inimigo número um e a objetividade, por vezes, é uma premissa básica. 